\title{
Method for determining bovine brucellosis vaccination coverage
}

\section{Método para determinar a cobertura vacinal para brucelose bovina}

\author{
Rosely Bianca dos Santos Kuroda ${ }^{1}$; Risia Lopes Negreiros ${ }^{2}$; Raul Ossada ${ }^{3}$; \\ José Soares Ferreira Neto ${ }^{4}$; Marcos Amaku'; Ricardo Augusto Dias ${ }^{4}$; \\ Evelise Oliveira Telles ${ }^{4}$; José Henrique Hildebrand Grisi-Filho ${ }^{4}$; \\ Marcos Bryan Heinemann ${ }^{4}$; Fernando Ferreira ${ }^{4 *}$
}

\begin{abstract}
In light of recent efforts in Brazil to increase B19 strain vaccine coverage of heifers, this study proposes a standardized methodology for the calculation of vaccination coverage among the Federal Units. To illustrate its use, the method was applied to data from the state of Mato Grosso to calculate vaccination coverage from 2006 to 2010 . The results provide the best estimate based on data currently available in most states and can be easily adapted to situations in which the cattle registries use different age categories from those used in the state of Mato Grosso.
\end{abstract}

Key words: Brucellosis. Bovine. Vaccination coverage.

\section{Resumo}

Tendo em vista o grande esforço que o Brasil vem fazendo para aumentar a cobertura vacinal de bezerras com a amostra B19, propõe-se metodologia padronizada para o cálculo da cobertura vacinal das Unidades Federativas. Para exemplificar sua utilização, o método foi aplicado aos dados do estado do Mato Grosso para calcular a cobertura vacinal no período de 2006 a 2010. Os resultados obtidos forneceram a melhor estimativa possível a partir dos dados atualmente disponíveis na maioria dos estados e pode ser facilmente adaptado para situações nas quais o registro do efetivo bovino se utilize de categorias etárias com amplitude diferente das utilizadas no estado do Mato Grosso.

Palavras-chave: Brucelose. Bovino. Cobertura vacinal.

${ }^{1}$ Discente, Faculdades Metropolitanas Unidas, FMU, São Paulo, SP, Brasil. E-mail: bibsantos@gmail.com

${ }^{2}$ Médica Veterinária, Instituto de Defesa Agropecuária do Estado de Mato Grosso, INDEA, Cuiabá, MT, Brasil. E-mail: risianegreiros@yahoo.com.br

${ }^{3}$ Discente, Faculdade de Medicina Veterinária e Zootecnia, Universidade de São Paulo, USP, São Paulo, SP, Brasil. E-mail: raulossada@gmail.com

${ }^{4}$ Profs., Faculdade de Medicina Veterinária e Zootecnia, USP, São Paulo, SP, Brasil. E-mail: grisi@vps.fmvz.usp.br; fernando@ vps.fmvz.usp.br; amaku@vps.fmvz.usp.br; dias@vps.fmvz.usp.br; evelise@vps.fmvz.usp.br; marcosbryan@usp.br; jsoares@ vps.fmvz.usp.br

* Author for correspondence 


\section{Introduction}

In 2001, Brazil launched the National Program for Control and Eradication of Brucellosis and Animal Tuberculosis (PNCEBT) (LAGE et al., 2006), which is consistent with the proposals of the World Organisation for Animal Health (Office International des Epizooties; OIE) and fundamentally based on the certification of independent farms, mandatory vaccination of heifers with the B19 and testing for movement of breeding animals. Following the launch of the PNCEBT, the Collaborating Centre for Animal Health, based at the Faculty of Veterinary Medicine and Animal Science, University of São Paulo, together with the Ministry of Agriculture and Food Supply (Ministério da Agricultura, Pecuária e Abastecimento; MAPA) and the official veterinary services, the states have conducted studies on the epidemiological situation of these two infections, aiming to generate high-quality data in order to choose the best strategies and develop management processes.

Studies on bovine brucellosis have been conducted in 18 states, which contain $85 \%$ of cattle in the country; these studies have reported a prevalence of outbreaks ranging from $0.32 \%$ to $41.6 \%$ in the states of Santa Catarina and Mato Grosso do Sul, respectively (ALVES et al., 2009; AZEVEDO et al., 2009; CHATE et al., 2009; DIAS et al., 2009a; DIAS et al., 2009b; GONÇALVES et al., 2009a; GONÇALVES et al., 2009b; KLEINGUNNEWIEK et al., 2009; MARVULO et al., 2009; OGATA et al., 2009; ROCHA et al., 2009; SIKUSAWA et al., 2009; SILVA et al., 2009; VILLAR et al., 2009; NEGREIROS et al., 2009; BORBA et al., 2013; ALMEIDA et al., 2016; CLEMENTINO et al., 2016).

Approximately 10 years after the first study, the states of Rondônia, Mato Grosso, Mato Grosso do Sul, São Paulo, Minas Gerais, Espirito Santo, and Rio Grande do Sul performed additional studies to check whether there was a decrease in the prevalence of bovine brucellosis as a result of vaccination programs implemented (BARDDAL et al., 2016; DIAS et al., 2016; ANZAI et al., 2016; INLAMEA et al., 2016; LEAL FILHO et al., 2016; OLIVEIRA et al., 2016; SILVA et al., 2016). The state of Santa Catarina, which has forbidden the vaccination with B19 strain and began implementing an eradication strategy, also conducted a second estimate of brucellosis prevalence to monitor its progress since 2001, when the first study was conducted (VILLAR et al., 2009; BAUMGARTEN et al., 2016). Table 1 shows that the vaccination program resulted in a decreased prevalence of infected herds in Minas Gerais, Rondonia, Mato Grosso, and Mato Grosso do Sul.

Table 1. Comparison of bovine brucellosis outbreak prevalence $(\mathrm{P})$ between the first and second studies carried out in Brazilian states, with an interval of approximately 10 years.

\begin{tabular}{lcccccc}
\hline \multirow{2}{*}{\multicolumn{1}{c}{ State }} & \multicolumn{3}{c}{ First study } & \multicolumn{3}{c}{ Second study } \\
\cline { 2 - 7 } & Year & $\mathrm{P}(\%)$ & CI95\% (\%) & Year & P (\%) & CI95\% (\%) \\
\hline Minas Gerais & 2002 & 6.04 & $4.98-7.10$ & 2011 & 3.59 & $2.76-4.42$ \\
Rondônia & 2004 & 35.18 & $32.09-38.36$ & 2014 & 12.3 & $10.3-14.6$ \\
Mato Grosso & 2003 & 41.2 & $38.0-44.4$ & 2014 & 24 & $21.3-26.8$ \\
Mato Grosso do Sul & 1998 & 41.6 & $37.0-46.3$ & 2009 & 30.6 & $27.4-34.0$ \\
Espírito Santo & $2002 / 2003$ & 9.0 & $6.97-11.55$ & $2012 / 2014$ & 9.3 & $7.1-11.8$ \\
Rio Grande do Sul & 2004 & 2.06 & $1.50-2.63$ & 2013 & 3.54 & $2.49-4.88$ \\
São Paulo & 2001 & 9.7 & $7.80-11.60$ & 2011 & 10.2 & $8.8-11.8$ \\
Santa Catarina & 2001 & 0.32 & $0.10-0.69$ & 2012 & 0.91 & $0.30-2.11$ \\
\hline
\end{tabular}

Source: Ferreira Neto et al., 2016. 
These data indicate that the vaccination of heifers with the B19 strain is a central part of the fight against brucellosis in Brazil; however, several states have not managed to lower the prevalence using this strategy. In order to address the failures of the vaccination programs implemented by the states, it is essential to audit the programs and obtain accurate estimates of vaccination coverage. Thus, this study proposes a standardized methodology for the calculation of vaccination coverage in the Brazilian Federal Units.

\section{Materials and Methods}

Vaccination coverage was calculated as the number of animals vaccinated (obtained from the number of certificates issued by veterinarians) divided by the number of animals in each monthly birth cohort.

Data generated by the state of Mato Grosso between 2006 to 2010 were used to illustrate the application of this method.

\section{Vaccination coverage}

The calculation of vaccination coverage involved estimating the numerator (number of animals vaccinated per year) and denominator (the number of potentially immunizable animals in the time period).

The value of the numerator was obtained objectively from the controlled sale of the vaccine. The purchase of vaccines is restricted to authorized veterinarians who are required to provide reports on their use and on the total number of immunized animals. The difficulty of the calculation of vaccination coverage is associated with determining the denominator because animal age may be divided into different categories.
To overcome this problem, the calculation of the number of potentially immunizable animals considers cohorts of monthly births. This method is based on the premise that births occur homogeneously within each age category, so if there are 60 animals in the category 0-6 months, 10 animals would have been born in the current month, 10 in the month before, and so on, until the sixth month.

To illustrate the application of the method, we used data from the state of Mato Grosso. In this state, cattle are recorded in the following age categories: animals of $0 \vdash 4 \mathrm{~m}, 4 \vdash 12 \mathrm{~m}, 12 \vdash 24 \mathrm{~m}, 24 \vdash$ $36 \mathrm{~m}$ and $\geq 36 \mathrm{~m}$. If other states use different age categories, adjustment of the calculation is simple.

Figure 1 shows the evolution of animal cohorts born in each month of the year, for a period of two years. Months in lighter colors represent periods in which the animal can be vaccinated.

If for instance, it is necessary to calculate vaccination coverage in year 2 , the numerator would be represented by the total number of animals vaccinated in the year, recorded on December $31^{\text {st }}$. For the calculation of the denominator, we initially assume that animals belonging to a particular cohort are vaccinated steadily over the period in which vaccination is possible. Thus, the law states that animals should be vaccinated after their third full month but before they complete their eighth month, a five-month period. Thus, one-fifth of the animals belonging to a particular cohort will be vaccinated in the first month, one-fifth in the second, and so on until the fifth month, when they complete their eighth months of life. 
Figure 1. Representation of the 24 hypothetical birth cohorts

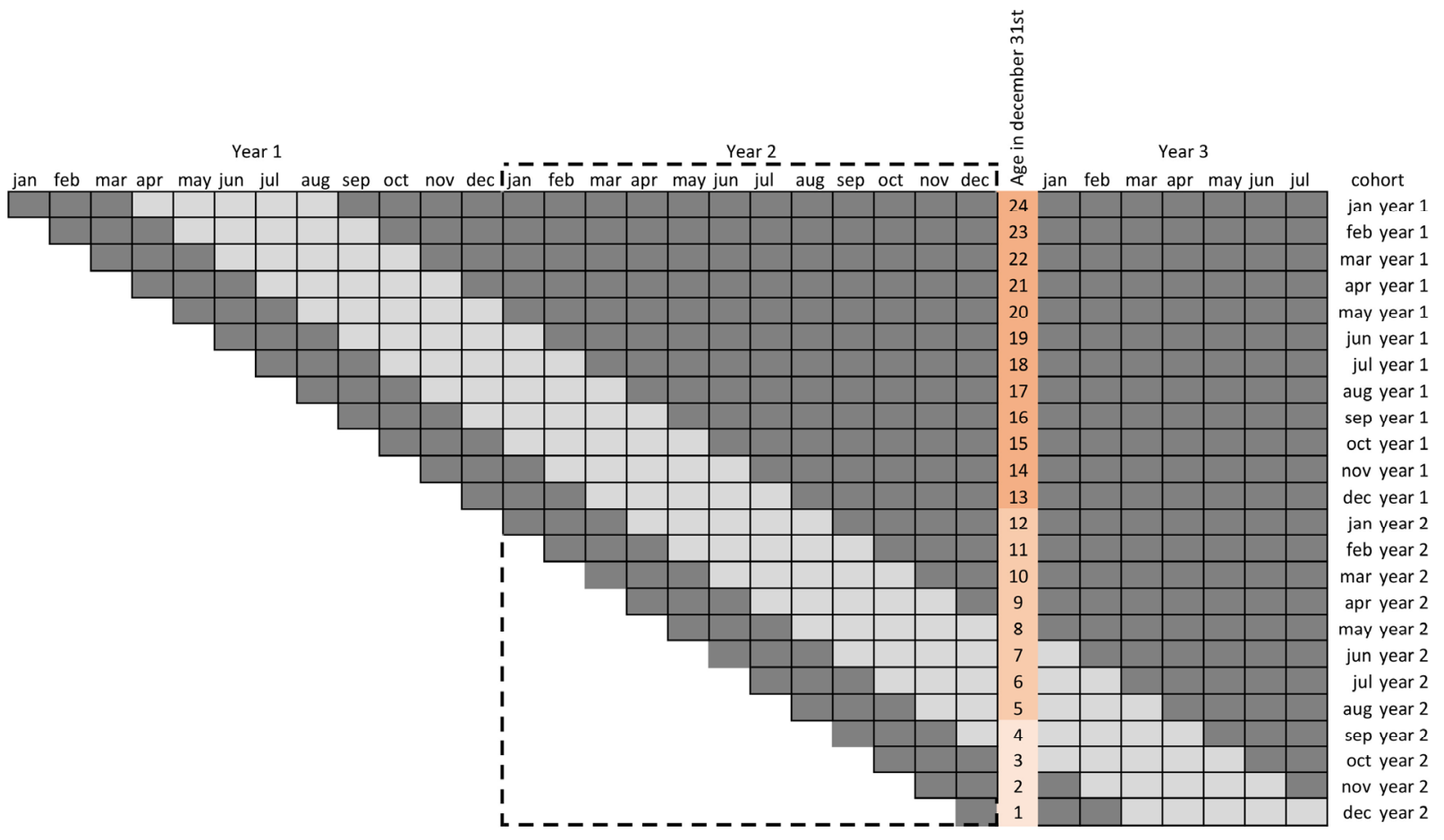

In this example scenario, all animals in the age categories of 0-4 m, 4-12 m, 12-24 m, 24-36 $\mathrm{m}$, and $\geq 36 \mathrm{~m}$ are registered in the state database on December $31^{\text {st }}$. The animals in the first age category are formed by cohorts born in December, November, October, and September of the second year. Assuming that there is no differential mortality for specific cohorts and, likewise, that there is no concentration of births in certain months and that the cattle population in the state is approximately constant over the years, we can assume that all animals in this category are divided equally in each cohort. Thus, one-quarter of the animals in this category belong to the December birth cohort, onequarter to those born in November and so on, until the month of September.

The cohort born in September may have already been vaccinated, as the animals would have been more than three months old in December. However, it is also possible that these animals were vaccinated in the following year; in this case, they should be included in the denominator of the following year. To resolve this problem we assume that only onefifth of the cohort born in September of year 2 would be vaccinated in this first month. The remaining would be vaccinated in the following year.

Thus, from the total number of animals in the 0 $\vdash 4 \mathrm{~m}$ category in December of the second year, only one-fifth of the animals belonging to the cohort born in September would be immunizable (onefourth of the total category); i.e., 1/20 of the total number of animals in this age category.

Considering the $4 \vdash 12 \mathrm{~m}$ age category, there are eight cohorts including animals born from January to August of year 2. As in the previous age group, we assumed that the existing animals in this age category are also evenly distributed across cohorts; that is, each cohort would have one-eighth of the total number of animals.

With regard to the number of immunizable animals, all cohorts born from January to May should have been vaccinated during year 2 (Figure 1). For the three remaining cohorts, using the same method, four-fifths of animals belonging to the cohort born in June, three-fifths of animals in the cohort born in July, and two-fifths of the animals belonging to the cohort born in August should 
have been vaccinated in year 2 . Thus, in the $4 \vdash$ 12 m category, 34/40 of the total number of animals should have been vaccinated.

The last relevant age category for the calculation includes animals in the $12 \vdash 24 \mathrm{~m}$ category. Twelve cohorts comprise this category, each with $1 / 12$ of the total number of animals. In this group, only animals born in cohorts from June of year 1 (the year before calculation) are immunizable.

Animals belonging to the previous five cohorts should have been vaccinated in the previous year.

Therefore, one-fifth of the cohort animals born in June of the previous year (year 1), two-fifths of the cohort animals born in July (year 1), three-fifths of the cohort animals born in August (year 1), and four-fifths of cohort animals born in September (year 1), in addition to all animals born in the October, November and December cohorts (year 1) should have been vaccinated in year 2 , representing $5 / 12$ of the total existing animals in this category.

In summary, the denominator of the calculation of vaccination coverage is the sum of $1 / 20$ of animals in the $0-4$ m category, 34/40 of animals in the $4 \vdash 12$ m category, and 5/12 of animals in the 12 $\vdash 24$ m category.

\section{Results}

The cattle herd in the state of Mato Grosso surpassed 27 million head in the period between 2009 to 2012, representing about $13 \%$ of the national herd and $39 \%$ of the existing herd in the Center-West region of Brazil.

Table 2 shows the distribution of cows according to the different age categories. The calculation of the number of immunizable females was performed as described above, and the results are shown in Table 3 , along with the number of vaccinated cows, and the estimation of the vaccine coverage during this period. The results based on this calculation provide the best possible estimate using data currently available in most states.

Table 3 shows a relatively stable vaccination coverage over the time period, with an average value of $83.83 \%$. The extremes of vaccination occurred in 2006 and 2008, with the highest and lowest coverage, respectively.

Table 2. Number of female bovine existing on December 31 st in the state of Mato Grosso between 2006 to 2010.

\begin{tabular}{lrrrrr}
\hline Females & $\mathbf{2 0 0 6}$ & $\mathbf{2 0 0 7}$ & $\mathbf{2 0 0 8}$ & $\mathbf{2 0 0 9}$ & $\mathbf{2 0 1 0}$ \\
\hline$<\mathbf{4} \mathbf{~ m}$ & $1,079,591$ & $1,061,748$ & $1,104,865$ & $1,207,878$ & $1,380,733$ \\
$\mathbf{4 - 1 2} \mathbf{~ m}$ & $1,641,459$ & $1,688,388$ & $1,745,527$ & $1,819,637$ & $2,080,989$ \\
$\mathbf{1 2 - 2 4} \mathbf{~ m}$ & $2,645,814$ & $2,649,304$ & $2,764,550$ & $2,696,839$ & $2,935,024$ \\
$\mathbf{2 4 - 3 6} \mathbf{~ m}$ & $2,531,297$ & $2,709,505$ & $2,790,710$ & $2,607,645$ & $2,677,794$ \\
$>\mathbf{3 6} \mathbf{~ m}$ & $7,785,555$ & $8,095,797$ & $8,827,450$ & $9,001,424$ & $9,528,089$ \\
TOTAL & $\mathbf{1 5 , 6 8 3 , 7 1 6}$ & $\mathbf{1 6 , 2 0 4 , 7 4 2}$ & $\mathbf{1 7 , 2 3 3 , 1 0 2}$ & $\mathbf{1 7 , 3 3 3 , 4 2 3}$ & $\mathbf{1 8 , 6 0 2 , 6 2 9}$ \\
\hline
\end{tabular}


Table 3. Number of immunizable heifers, number of vaccinated heifers, and vaccination coverage against bovine brucellosis in the state of Mato Grosso, 2006 to 2010.

\begin{tabular}{|c|c|c|c|c|c|}
\hline & 2006 & 2007 & 2008 & 2009 & 2010 \\
\hline Immunizable & $2,551,642$ & $2,592,094$ & $2,690,837$ & $2,730,768$ & $3,060,804$ \\
\hline Immunized & $2,271,239$ & $2,141,152$ & $2,210,052$ & $2,273,937$ & $2,514,537$ \\
\hline Coverage & $89.01 \%$ & $82.60 \%$ & $82.13 \%$ & $83.27 \%$ & $82.15 \%$ \\
\hline
\end{tabular}

\section{Discussion}

The states in Brazil have used different methods to calculate the denominator for vaccination coverage and have requested guidance from the MAPA on the best way to perform this estimation. The problem is complex and stems from two factors: the first is associated with the time period in which animals can be vaccinated, which can vary each year, making it difficult to determine in which year we should count individual animals. The second difficulty is associated with the fact that animals are included based on different age categories, which may differ between states. Thus, for example, from the total number of animals between 12 and 24 months of age included in the register on December $31^{\text {st }}$, it is not clear which fraction should be considered to be potentially immunizable that year.

These complexities generate problems that can only have approximate solutions. Thus, the use of monthly birth cohorts may provide an acceptable solution.

By assuming that animals of a given cohort are vaccinated steadily over the period in which vaccination is permitted, the problem of which fractions of this population to include in each year is solved. Similarly, assuming that births are evenly distributed offers an approximate solution to the problem by knowing what fraction of individuals in each age category belongs to each cohort.

These two assumptions are very strong. However, even if there was a small cluster of events around a certain date, related to birth or vaccination, this effect would be compensated for when considering the years in aggregate. Therefore, the possible loss of potentially immunizable animals in a year due to postponing vaccination until the following year would be compensated by the same type of flow from the previous year to the current.

There is no simple solution that is without potential issues or criticisms; however, we believe that this method offers a standardization that ensures the comparability of data between states.

\section{Conclusions}

The results obtained using this standardized methodology provide the best possible estimate based on data currently available in most states; the method can also be easily adapted to situations in which cattle registries use different age categories than those used in the state of Mato Grosso.

\section{Acknowledgements}

The authors acknowledge the support from MAPA, CNPq and FAPESP.

\section{References}

ALMEIDA, E. C.; FREITAS, A. A.; PONTUAL, K. A. Q.; SOUZA, M. M. A.; AMAKU, M.; DIAS, R. A.; FERREIRA, F.; TELLES, E. O.; HEINEMANN, M. B.; GONÇALVES, V. S. P.; EVÊNCIO NETO, J.; MARVULO, M. F. V.; GRISI-FILHO, J. H. H.; FERREIRA NETO, J. S.; SILVA, J. C. R. Prevalence and associated risk factors for bovine brucellosis in the state of Pernambuco, Brazil. Semina: Ciências Agrárias, Londrina, v. 37, n. 5, p. 3413-3424, 2016. Suplemento 2.

ALVES, A. J. S.; GONÇALVES, V. P. S.; FIGUEIREDO, V. C. F.; LOBO, J. R.; BAHIENSE, L.; AMAKU, M.; FERNANDO, F.; FERREIRA NETO, J. S.; DIAS, R. A. 
Situação epidemiológica da brucelose bovina no Estado da Bahia. Arquivo Brasileiro de Medicina Veterinária e Zootecnia, Belo Horizonte, v. 61, p. 6-13, 2009. Suplemento 1.

ANZAI, E. K.; COSTA, D.; SAID, A. L. P. R.; GRISI-FILHO, J. H. H.; AMAKU, M.; DIAS, R. A.; FERREIRA, F.; GALVIS, J. O. A.; GONÇALVES, V. S. P.; HEINEMANN, M. B.; TELLES, E. O.; FERREIRA NETO, J. S. An update on the epidemiological situation of bovine brucellosis in the state of Espírito Santo, Brazil. Semina: Ciências Agrárias, Londrina, v. 37, n. 5, p. 3437-3448, 2016. Suplemento 2.

AZEVEDO, S. S.; FERREIRA NETO, J. S.; DIAS, R. A.; FERREIRA, F.; AMAKU, M.; FIGUEIREDO, V. C. F.; LOBO, J. R.; GONÇALVES, V. S. P.; SOUZA, A. C.; VASCONCELLOS, S. A. Situação epidemiológica da brucelose bovina no Estado do Espírito Santo. Arquivo Brasileiro de Medicina Veterinária e Zootecnia, Belo Horizonte, v. 61, p. 19-26, 2009. Suplemento 1.

BARDDAL, J. E. I.; SANTOS, J. C. Q.; LOPES, I. F.; FERREIRA NETO, J. S.; FERREIRA, F.; AMAKU, M.; DIAS, R. A.; TELLES, E. O.; GRISI-FILHO, J. H. H.; HEINEMANN, M. B.; GONÇALVES, V. S. P.; AGUIAR, D. M. Effect of vaccination in lowering the prevalence of bovine brucellosis in the state of Mato Grosso, Brazil. Semina: Ciências Agrárias, Londrina, v. 37, n. 5, p. 3479-3492, 2016. Suplemento 2.

BAUMGARTEN, K. D.; VELOSO, F. P.; GRISI-FILHO, J. H. H.; FERREIRA, F.; AMAKU, M.; DIAS, R. A.; TELLES, E. O.; HEINEMANN, M. B.; GONÇALVES, V. S. P.; FERREIRA NETO, J. S. Prevalence and risk factors for bovine brucellosis in Santa Catarina State, Brazil. Semina: Ciências Agrárias, Londrina, v. 37, n. 5, p. X-X, 2016. Suplemento 2.

BORBA, M. R.; STEVENSON, M. A.; GONÇALVES, V. S. P.; FERREIRA NETO, J. S.; FERREIRA, F.; AMAKU, M.; TELLES, E. O.; SANTANA, S. S.; FERREIRA, J. C. A.; LOBO, J. R.; FIGUEIREDO, V. C. F.; DIAS R. A. Prevalence and risk-mapping of bovine brucellosis in Maranhão state, Brazil. Preventive Veterinary Medicine, Colorado, v. 110, p. 169-176, 2013.

CHATE, S. C.; DIAS, R. A.; AMAKU, M.; FERREIRA, F.; MORAES, G. M.; COSTA NETO, A. A.; MONTEIRO, L. A. R. C.; LOBO, J. R.; FIGUEIREDO, V. C. F.; GONÇALVES, V. S. P.; FERREIRA NETO, J. S. Situação epidemiológica da brucelose bovina no Estado do Mato Grosso do Sul. Arquivo Brasileiro de Medicina Veterinária e Zootecnia, Belo Horizonte, v. 61, p. 46-55, 2009. Suplemento 1.

CLEMENTINO, I. J.; DIAS, R. A.; AMAKU, M.; FERREIRA, F.; TELLES, E. O.; HEINEMANN, M.
B.; GONÇALVES, V. S. P.; GRISI-FILHO, J. H. H.; FERREIRA NETO, J. S.; ALVES, C. J.; SANTOS, C. S. A. B.; AZEVEDO, S. S. Epidemiological situation of bovine brucellosis in the state of Paraiba, Brazil. Semina: Ciências Agrárias, Londrina, v. 37, n. 5, p. 3403-3412, 2016. Suplemento 2.

DIAS, J. A.; MÜLLER, E. E.; DIAS, R. A.; FREITAS, J. C.; AMAKU, M.; FERREIRA, F.; SILVA, M. C. P.; LOBO, J. R.; FIGUEIREDO, V. C. F.; GONÇALVES, V. S. P.; FERREIRA, NETO, J. S. Situação epidemiológica da brucelose bovina no Estado do Paraná. Arquivo Brasileiro de Medicina Veterinária e Zootecnia, Belo Horizonte, v. 61, p. 66-76, 2009a. Suplemento 1.

DIAS, R. A.; BELCHIOR, A. P. C.; FERREIRA, R. S.; GONÇALVES, R. C.; BARÃO. R. S. C.; SOUSA, P. R.; SANTOS, A. M. A.; AMAKU, M.; FERREIRA, F.; TELLES, E. O.; GRISI-FILHO, J. H. H.; HEINEMANN, M. B.; GONÇALVES, V. S. P.; FERREIRA NETO, J. S. Controlling bovine brucellosis in the State of São Paulo, Brazil: results of ten years of vaccination program. Semina: Ciências Agrárias, Londrina, v. 37, n. 5, p. 3505-3518, 2016. Suplemento 2.

DIAS, R. A.; GONÇALVES, V. S. P.; FIGUEIREDO, V. C. F.; LOBO, J. R.; LIMA, Z. M. B.; PAULIN, L. M. S.; GUNNEWIEK, M. F. K.; AMAKU, M.; FERREIRA NETO, J. S.; FERREIRA, F. Situação epidemiológica da brucelose bovina no Estado de São Paulo. Arquivo Brasileiro de Medicina Veterinária e Zootecnia, Belo Horizonte, v. 61, p. 118-125, 2009b. Suplemento 1.

FERREIRA NETO, J. S.; SILVEIRA, G. B.; ROSA, B. M.; GONÇALVES, V. S. P.; GRISI-FILHO, J. H. H.; AMAKU, M.; DIAS, R. A.; FERREIRA, F.; HEINEMANN, M. B.; TELLES, E. O.; LAGE, A. P. Analysis of 15 years of the National Program for the Control and Eradication of Animal Brucellosis and Tuberculosis, Brazil. Semina: Ciências Agrárias, Londrina, v. 37, n. 5, p. 3385-3402, 2016. Suplemento 2.

GONÇALVES, V. S. P.; DELPHINO, M. K. V. C.; DIAS, R. A.; FERREIRA, F.; AMAKU, M.; FERREIRA NETO, J. S.; PORTO, T. B.; ALVES, C. M.; FIGUEIREDO, V. C. F.; LOBO, J. R. Situação epidemiológica da brucelose bovina no Estado de Minas Gerais. Arquivo Brasileiro de Medicina Veterinária e Zootecnia, Belo Horizonte, v. 61, p. 35-45, 2009a. Suplemento 1.

GONÇALVES, V. S. P.; RIBEIRO, L. A.; CALDAS, R. A.; FRANCISCO, P. F. C.; DIAS, R. A.; FERREIRA, F.; AMAKU, M.; FERREIRA NETO, J. S.; FIGUEIREDO, V. C. F.; LOBO, J. R.; BORGES, J. R. J. Situação epidemiológica da brucelose bovina no Distrito Federal. Arquivo Brasileiro de Medicina Veterinária e Zootecnia, Belo Horizonte, v. 61, p. 14-18, 2009b. Suplemento 1. 
INLAMEA, O. F.; ROCHA, A. B.; FERREIRA, F.; GRISI-FILHO, J. H. H.; HEINEMANN, M. B.; DIAS, R. A.; TELLES, E. O.; GONÇALVES, V. S. P.; AMAKU, M.; FERREIRA NETO, J. S. Effect of vaccination in lowering bovine brucellosis in the state of Rondônia, Brazil. Semina: Ciências Agrárias, Londrina, v. 37, n. 5, p. 3493-3506, 2016. Suplemento 2.

KLEIN-GUNNEWIEK, M. F. C.; AMAKU, M.; DIAS, R. A.; FERREIRA, F.; GITTI, C. B.; PEREIRA, L. A.; FIGUEIREDO, V. C. F.; LOBO, J. R.; GONÇALVES, V. S. P.; FERREIRA NETO, J. S. Situação epidemiológica da brucelose bovina no Estado do Rio de Janeiro. Arquivo Brasileiro de Medicina Veterinária e Zootecnia, Belo Horizonte, v. 61, p. 77-84, 2009. Suplemento 1.

LAGE, A. P.; ROXO, E.; MÜLLER, E.; POESTER, F.; CAVALLÉRO, J. C. M.; FERREIRA NETO, J. S.; MOTA, P. M. P. C.; GONÇALVES, V. S. P. Programa nacional de controle e erradicação da brucelose e da tuberculose animal (PNCEBT). Brasília: Ministério da Agricultura, Pecuária e Abastecimento, 2006. 184 p. (Manual técnico).

LEAL FILHO, J. M.; BOTTENE, I. F. N.; MONTEIRO, L. A. R. C.; PELLEGRIN, A. O.; GONÇALVES, V. S. P.; FERREIRA, F.; DIAS, R. A.; AMAKU, M.; TELLES, E. O.; GRISI-FILHO, J. H. H.; HEINEMANN, M. B.; FERREIRA NETO, J. S Control of bovine brucellosis from 1998 to 2009 in the state of Mato Grosso do Sul, Brazil. Semina: Ciências Agrárias, Londrina, v. 37, n. 5, p. 3467-3478, 2016. Suplemento 2 .

MARVULO, M. F. V.; FERREIRA, F.; DIAS, R. A.; AMAKU, M.; GROFF, A. C. M.; GONÇALVES, V. S. P.; FIGUEIREDO, V. C. F.; LOBO, J. R.; FERREIRA NETO, J. S. Situação epidemiológica da brucelose bovina no Estado do Rio Grande do Sul. Arquivo Brasileiro de Medicina Veterinária e Zootecnia, Belo Horizonte, v. 61, p. 93-102, 2009. Suplemento 1.

NEGREIROS, R. L.; DIAS, R. A.; FERREIRA, F.; FERREIRA NETO, J. S.; GONÇALVES, V. S. P.; SILVA, M. C. P.; FIGUEIREDO, V. C. F.; LOBO, J. R.; FREITAS, J.; AMAKU, M. Situação epidemiológica da brucelose bovina no Estado do Mato Grosso. Arquivo Brasileiro de Medicina Veterinária e Zootecnia, Belo Horizonte, v. 61, p. 56-65, 2009. Suplemento 1.

OGATA, R. A.; GONÇALVES, V. S. P.; FIGUEIREDO, V. C. F.; LOBO, J. R.; RODRIGUES, A. L.; AMAKU, M.; FERREIRA, F.; FERREIRA NETO, J. S.; DIAS, R. A. Situação epidemiológica da brucelose bovina no Estado do Tocantins. Arquivo Brasileiro de Medicina Veterinária e Zootecnia, Belo Horizonte, v. 61, p. 126134, 2009. Suplemento 1.
OLIVEIRA, L. F.; DORNELES, E. M. S.; MOTA, A. L. A. A.; GONÇALVES, V. S. P.; FERREIRA NETO, J. S.; FERREIRA, F.; DIAS, R. A.; TELLES, E. O.; GRISIFILHO, J. H. H.; HEINEMANN, M. B.; AMAKU, M.; LAGE, A. P. Seroprevalence and risk factors for bovine brucellosis in the State of Minas Gerais, Brazil. Semina: Ciências Agrárias, Londrina, v. 37, n. 5, p. 3449-3446, 2016. Suplemento 2.

ROCHA, W. V.; GONÇALVES, V. S. P.; COELHO, C. G. N. F. L.; BRITO, W. M. E. D.; DIAS, R. A.; DELPHINO, M. K. V. C.; FERREIRA, F.; AMAKU, M.; FERREIRA NETO, J. S.; FIGUEIREDO, V. C. F.; LOBO, J. R.; BRITO, L. A. B. Situação epidemiológica da brucelose bovina no Estado de Goiás. Arquivo Brasileiro de Medicina Veterinária e Zootecnia, Belo Horizonte, v. 61, p. 27-34, 2009. Suplemento 1.

SIKUSAWA, S.; AMAKU, M.; DIAS, R. A.; FERREIRA NETO, J. S.; MARTINS, C.; GONÇALVES, V. S. P.; FIGUEIREDO, V. C. F.; LOBO, J. R.; FERREIRA, F. Situação epidemiológica da brucelose bovina no Estado de Santa Catarina. Arquivo Brasileiro de Medicina Veterinária e Zootecnia, Belo Horizonte, v. 61, p. 103108, 2009. Suplemento 1.

SILVA, N. S.; GROFF, A. C. M.; VIDOR, A. C. M.; GRISI-FILHO, J. H. H.; HEINEMANN, M. B.; DIAS, R. A.; TELLES, E. O.; GONÇALVES, V. S. P.; AMAKU, M.; FERREIRA, F.; FERREIRA NETO, J. S. Epidemiological situation of bovine brucellosis after implementation of a vaccination program in Rio Grande do Sul state, Brazil. Semina: Ciências Agrárias, Londrina, v. 37, n. 5, p. 3519-3520, 2016. Suplemento 2.

SILVA, V.G. S. O.; DIAS, R.A.;FERREIRA, F.;AMAKU, M.; COSTA, E. L. S.; LOBO, J. R.; FIGUEIREDO, V. C. F.; GONÇALVES, V. S. P.; FERREIRA NETO, J. S. Situação epidemiológica da brucelose bovina no Estado de Sergipe. Arquivo Brasileiro de Medicina Veterinária e Zootecnia, Belo Horizonte, v. 61, p. 109-117, 2009. Suplemento 1.

VILLAR, K. S.; AMAKU, M.; DIAS, R. A.; FERREIRA NETO, J. S.; BENITEZ, F.; GONÇALVES, V. S. P.; FIGUEIREDO, V. C. F.; LOBO, J. R.; FERREIRA, F. Situação epidemiológica da brucelose bovina no Estado de Rondônia. Arquivo Brasileiro de Medicina Veterinária e Zootecnia, Belo Horizonte, v. 61, p. 85-92, 2009. Suplemento 1. 